\title{
Linking net entry to regional economic growth
}

\author{
Marcus Dejardin
}

Accepted: 31 October 2009/Published online: 19 December 2009

(C) The Author(s) 2009. This article is published with open access at Springerlink.com

\begin{abstract}
Regional growth differentials could be explained by how intensively and dynamically new firms of a particular region enter expanding industries. Although the direct contribution of new firms to value creation and growth may be regarded as tautological, the aggregate impacts are largely empirically unobserved. After a brief motivation, we use an expression of firm net entry as an indicator of the distinctive capacity of regional entrepreneurial resources to enter new industries and create value. Using data for Belgian districts, we test the net entry effects on subsequent economic growth in the manufacturing and services industries. Our analysis helps emphasize the different dynamics at work within the manufacturing and services industries and, although requiring cautious interpretation, provides evidence for some positive impact of net entry on regional economic growth in the services industry.
\end{abstract}

Keywords Net entry · Entrepreneurship ·

Economic growth $\cdot$ Region

M. Dejardin $(\square)$

Faculty of Economics, Social Sciences and Business

Administration, FUNDP-University of Namur,

Rempart de la Vierge, 8, 5000 Namur, Belgium

e-mail: marcus.dejardin@fundp.ac.be

M. Dejardin

Erasmus University Rotterdam, Rotterdam,

The Netherlands
JEL Classifications L26 - M13 .

$\mathrm{O} 40 \cdot \mathrm{O} 18$

\section{Introduction}

Consistent with economic literature originating with the seminal works of Schumpeter (1911, 1942), contemporary economists and policy advisers now view entrepreneurship as the process carrying innovations into the economy, thus contributing to economic growth. ${ }^{1}$ Although there are numerous empirical contributions emphasizing the positive impact of entrepreneurship on economic performance at the firm level, ${ }^{2}$ linkage at the more aggregated, economy-wide level is still a matter of concern for several scholars. Although the direct contribution of new firms to economic growth may be regarded as tautological, aggregate impacts including the indirect effects of new firms are largely empirically unnoticed.

Actually the collected evidence is rather weak, in particular when the entrepreneurial dynamism of an economy is identified by the flows of new and exiting firms. A gap is even acknowledged in this respect, with reference to countries, despite some ongoing efforts including the Global Entrepreneurship Monitor

\footnotetext{
1 Aghion and Howitt (1992), Wennekers and Thurik (1999), Carree and Thurik (2003), Audretsch et al. (2006), and Friis et al. (2006).

${ }^{2}$ For an extended review, see Audretsch (2002).
} 
(Carree and Thurik 2003; van Stel, Carree and Thurik 2005; see as well Carree and Thurik 2008). Regarding empirical evidence at the regional (infranational) level, the situation appears to be slightly different, conditional on the availability of reliable data.

As firm birth and death rates vary among the regions of a given country, there is a potential source of explanation for the spatial variations of economic growth or employment. Although some studies consider the relationship between entrepreneurial measures and employment ${ }^{3}$ or productivity, ${ }^{4}$ attempts directly linking firm births and deaths to the regional aggregate product or aggregated value added remain exceptional. ${ }^{5}$ The present paper contributes to filling this gap by testing the net entry effects on subsequent economic growth, in terms of gross domestic product (GDP) growth, in the manufacturing and services industries in Belgium.

Conflicting results suggest that it is appropriate to investigate more closely the entrepreneurial processes taking place. In particular, it suggests that careful consideration of the industrial composition of the regional economy (as opposed to aggregate assessments) and the effective industrial dynamics due to the entries and exits of firms could reveal new insights. The present paper falls under this heading. Noticeable antecedents, albeit focusing on the effects of firm entry and exit on employment (not aggregate value added), are those by Audretsch and Fritsch (1996, 2002), Fritsch (1996, 1997), and Fritsch and Mueller (2004, 2008).

While challenging and illuminating the framework for growth affecting economies in the long run, the explanatory power of Schumpeterian theories seems more limited for growth differentials between regions in the short and medium term. For this latter issue, we suggest herein that the net birth rate of firms, considered by region and industry, could be a good, albeit imperfect, indicator of the extent to which the entrepreneurial resources in a specific region are moving

\footnotetext{
${ }^{3}$ E.g., Ashcroft and Love (1996), Fritsch (1997), Foelster (2000), van Stel and Storey (2004), Acs and Armington (2004), van Stel and Suddle (2008), and Fritsch (2008).

${ }^{4}$ Callejon and Segarra (1999), Braunerhjelm and Borgman (2004), and Bosma et al. (in this issue).

5 Johnson and Parker (1996), examining the lag effects of firm births and deaths on production growth at the UK county level for 1990, established a positive and significant relationship.
}

toward profitable expanding industries, contributing to regional prosperity. As other authors point out (Beesley and Hamilton 1984; Geroski 1995; Caves 1998), firm demography can vary substantially in intensity from one industry to another. A strict aggregate approach, using net birth rates without taking into account industrial economic structures, involves the risk of significantly altering the entrepreneurial processes at work in a given region. This argument requires a sector-adjusted indicator (Fritsch 1996). Moreover, as the most detailed industrial classification of firm births and deaths currently available cannot account for the emergence of new products and industries (Beesley and Hamilton 1984), the indicator must be defined in such a way that it reflects the dedication of entrepreneurial resources toward new expanding industries, as would do the net birth rate.

In the empirical part of this paper, we test a sectorally adjusted expression of the net entry rate of firms as a factor explaining the growth differentials between regions. The growth is in terms of aggregated value added. The data refer to the manufacturing and services industries and to the Belgian administrative districts (the 43 arrondissements) for the period 19821996. Results help to emphasize the different dynamics at work within the manufacturing and services industries and, although requiring cautious interpretation, provide evidence of some positive impact of net entry on regional economic growth in the services industry.

The structure of the paper is as follows. In the next section, the links between net entry and regional economic growth are discussed given antecedent literature, and discussion points underlying this empirical study are suggested. In the third section a description of the data and the definition of the indicators used in the correlation are presented, while the regression and dynamic panel regression analyses are conducted in the fourth section. The fifth and final section is dedicated to the conclusions.

\section{Net entry and economic growth}

An extended empirical literature is devoted to the study of firm demography. Several studies have focused on firm births and deaths (or the creation and cessation of economic activities), and more particularly on the regional factors entering into the explanation of spatial variations of firm entry and 
exit rates. ${ }^{6}$ Some contributions integrate the regional population or GDP growth into the deterministic part of the econometric models, thus identifying in an increasing demand a potential source for entrepreneurial dynamics (Reynolds et al. 1994).

If there are quite a lot of arguments-economic growth being included-entering into the explanation of the spatial variations in firm birth and death rates, a critical question for economists and policy advisers centers on the impact of these entrepreneurial processes on subsequent economic growth rate. A main positive feedback effect, from entrepreneurial demography to economic growth, should result from the innovation conveyed. Both Audretsch and Fritsch (1996) and Fritsch (1996) discuss the link between industry turbulence (defined as "the simultaneous movement of firms into and out of a market", Audretsch and Fritsch 1996, p. 138) and economic growth. Their research is based on Schumpeter's wellknown theory of creative destruction (1942). ${ }^{7}$ To succeed in entering the market, especially under conditions including both the unconstrained production capacities of the incumbent firms and no expanding demand, a new firm must innovate. Thus, firm entry is not simply new and additional production, but rather it is a disequilibrating agent. By either producing more efficiently or producing better goods and services, the existence of a new firm implies firm exits. According to the argument, the intensity of the observed turbulence would be an indicator of the innovative processes that affect and ultimately renew economic activities. The potential productivity increases, as well as resource reallocation which becomes possible consequently and through firm exits, should foster competitive advantage and overall economic development. Thus, high turbulence should be positively correlated with subsequent economic growth.

Some general considerations combined with empirical evidence induce several circumstantial comments about the Schumpeterian argument. Can firm turbulence be definitely associated with innovative processes? Actually, firm birth and death rates seem to be

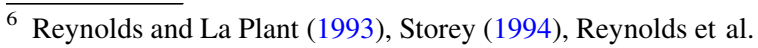
(1994), Spilling (1996), Kangasharju (2000), Acs and Armington (2002), Azevedo et al. (2003), Gaygisiz and Köksal (2003), and Ashcroft et al. (2007).

7 See Aghion and Howitt $(1992,1998)$ for a first and stimulating formalization.
}

determined by many factors. In some cases, exits are best explained by reasons internal to the firm such as inexperience and mismanagement (as regularly reported in Dun and Bradstreet's Business Failure Record) or the entrepreneur's retirement rather than by innovative entries. It can be argued, moreover, that incumbent firms can also innovate and induce productivity increases, and consequently facilitate some exits. To obtain this result, the threat of entry (not actual entry) would be sufficient, as suggested by the theory of contestable markets (Baumol et al. 1982).

In some sectors, such as in the retailing and consumer services industries, numerous entries and exits are observed, ${ }^{8}$ but the actual innovative content is unknown. At most we see in the regular closing down and reopening of clothing shops in cities the effect of either upstream industrial changes, or the consequences of individual job reorientation and concrete experience of the optimal allocation of resources.

In contrast, abundant literature emphasizes that positive net entry of firms in markets for new products and emerging industries (see among others Gort and Klepper 1982; Klepper and Graddy 1990; Jovanovic and MacDonald 1994; Klepper 1996; Agarwal and Gort 1996) is a result of innovative activities. Moreover, a stylized path in the number of entries, exits, and firms for an entire industry lifecycle has been proposed (Fig. 1; Fritsch 1996).

Profit expectations, given low competition and increasing demand, may explain the positive net entry in the early stages of the market, maturity being characterized by a high number of incumbents, higher competition, and lower entry rates. Notice that the gross entry rate associated with the early stages is generally depicted as being much larger than net entry. This is due to high rates of mortality among new firms (Caves 1998). Later on, as productivity increases while trade value declines, the number of firms decreases dependent upon the magnitude of the negative net entry rate.

\footnotetext{
$\overline{8}$ So, it appears from statistics for the year 2002 published by the Belgian federal administration (Economie, Démographie des enterprises, Direction Générale Statistique et Information Economique, Bruxelles, 2004) that the number of registrations (births) and deletions (deaths) from value-added tax registration books in the retailing industry (trade and repair of vehicles excepted) represents, respectively, 2.6 and 2.7 times the corresponding statistics for the entire manufacturing industry (except the building industry).
} 


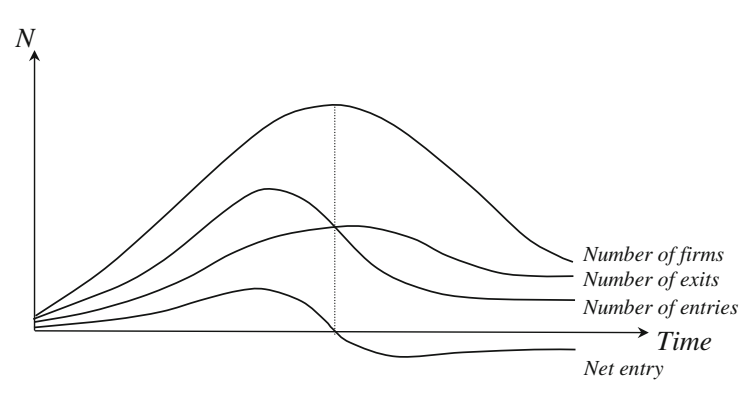

Fig. 1 Stylized paths in the number of entries, exits, and firms over the industry lifecycle. Source: Fritsch (1996); see also Audretsch (1995) and Klepper (1996)

So, Peneder (2008) concludes, in a recent empirical study based on Organisation for Economic Co-operation and Development (OECD) firm-level data, that the "nexus of entry and turnover with profitability and growth is more complex than initially anticipated" (p. 340). The evidence is, however, for a positive relationship between growth of value added and entrepreneurial industries characterized by a high turnover and a growing firm population, i.e., positive net entry.

Hence, the turnover of firms reflects the development of the industry of which they are a part. A positive net entry (birth) rate indicates the manner in which the entrepreneurial resources in a specific region are moving toward expanding economic sectors, allowing the greatest profit expectations. On the contrary, negative net entry rates indicate the presence of more mature and/or even declining industries in the regional industrial portfolio.

By creating value, new firms contribute positively to the product of the country or the region where they are located. This is the direct effect (the contribution of the new firms to the aggregate product), but this is also tautological. More significant are the joint direct and indirect effects of the new firms (Fritsch and Mueller 2004), as entry: (1) is not without impact on the incumbent firms, and (2) determines exits, as suggested above. In the short or medium term, the expected impact of new firm entry on incumbents is increased Bertrand price competition, reducing overall industrial profitability, and/or Cournot quantity competition, affecting each firm's total revenue. New firms may also promote innovation among incumbents, thus enhancing their efficiency, with positive effects on the value added of the industry. With respect to firm exits, it appears tautological that the disappearance of firms affects directly and negatively the industry's value added. Whether this is more or less counterbalanced by the action of new firms is uncertain, while raising the question of the synchronicity of opposite effects. From the demand side, decreased prices may positively affect the purchasing power of consumers, allowing increased expenditure on other goods and services and, in turn, higher profitability for those concerned industries. The expected sign of the net effects is thus unclear and, as such, is of concern for empirical research.

Assessment of net entry effects from a more specific regional perspective results in highlighting two potential outcomes. First, according to the most favorable scenario, as a regional portfolio of activities extends into new industries, it attracts purchasing power from outside the region. Greater market size and product variety increase the attractiveness of the region. This relationship is known in regional economics as Reilly's law (1931) of retail gravitation. Therefore, dynamic markets can exert a pull on customers from outside the region, increasing total receipts at one location at the expense of other regions. The second potential outcome is that, if the regional supply is varied, it limits expenditure on external goods and services, which, in macroeconomics terminology, limits import leakage. Other effects are not to be underestimated. In particular, manufacturing that needs a variety of (new) inputs and is concentrated in one or another location may attract other firms to the neighborhood.

Based on this discussion we can identify four salient discussion points:

1. In accordance with the industry lifecycle literature, positive net entry rates may be linked to new products and emerging industries.

2. Empirical evidence collected at the firm level identifies a positive relationship between value added and industries characterized by high turnover and growing firm population (hence, positive net entry).

3. Direct and indirect effects of new firms determine the aggregate outcome in terms of industry value added. The expected sign of the net effects is a priori unclear and thus is a matter of concern for empirical research.

4. For regions, extending into new industries facilitates self-reliance and attractiveness, contributing to lasting prosperity. 
These lead to the proposition that regions whose entrepreneurial resources are entering the industries with the highest positive net entry rates will achieve greater performance in terms of economic growth, which is tested empirically.

Before the empirics, two additional remarks are important. First, due to the inherent imprecision of any industrial aggregated classification, gaps exist between the actual economic activities of a region and the statistics. As previously noted, the most detailed industrial classification of firm births and deaths is unable to identify the emergence of new products and industries (Beesley and Hamilton 1984). In order to limit this gap, indicators must be defined in such a way that they reflect the inclination of new entrepreneurial firms to enter new expanding industries. One way to achieve this, at least partly, is by integrating additional information into the net entry indicator by comparing specific net entry rates of a given region with an average (national) rate. Second and finally, as new firms' (direct and indirect) contributions to the economic processes can be very small initially, but increasing over time (Foster, Haltiwanger and Krizan 1998), econometric models should allow for lagged effects. These concerns are addressed by the empirical strategy used.

\section{Data and variables}

Quantitative assessment of entrepreneurial activity in Belgium is not an easy task. The existing data sets ${ }^{9}$ each have drawbacks in terms of continuity and homogeneity of definition, as well as the level of geographical and industrial disaggregation. The Belgian Directorate General Statistics collected the data used in this study. The data cover a period of 15 years, from 1982 to 1996, and are extracted from the books of the value-added tax authorities. It includes the stock of active taxable self-employed agents or firms at the beginning of each year, as well as the registrations and deletions from the VAT registration books

\footnotetext{
9 The main providers are the Belgian Directorate General Statistics (DGS), the value-added tax (VAT) administration, the National Office for Social Security, the National Institute for Social Security of Self-Employed People, the commercial registers, and private companies such as Euro-DB, Graydon, and Gerling Belgium.
}

occurring during that year. Note that new registration does not mean univocally the creation of a new activity (creation ex nihilo), as it can also indicate a change in ownership. In this case, registration is generally counterbalanced by a deletion, but not in every case. At the same time, deletions do not inevitably indicate the disappearance of economic activity, as they may result from mergers or absorption.

To be counted as creations at the end of the year, the new registered firms must still be active at that moment. ${ }^{10}$ Annual deletions, on the other hand, are added up without any conditions. Accordingly, there can be a systematic undercount of the net new registrations. This and other possible statistical shortcomings are controlled for by using the information given by the stock of firm differences, as the stock of firms at time $t$ minus the stock at time $t-1$ should be equal to entries between $t-1$ and $t$ minus exits between $t-1$ and $t$.

Undoubtedly an advantage of this dataset is the high degree of industrial and geographical detail available. This dataset has industrial classification available at a two-digit level of the Classification of Economic Activities in the European Community (NACE) and for the 43 Belgian districts (arrondissements). One handicap is its heterogeneity with respect to, on the one hand, the type of agents (individuals or companies ${ }^{11}$ ) and, on the other hand, the criterion of geographical localization (abode place or working place for individuals; registered office place or, exceptionally, place at which VAT is declared for companies ${ }^{12}$ ). Moreover there is the problem that smaller geographical units lead to greater problems with measurement error. However, the abode or registered office location and the working or plant location probably coincide to a large extent with respect to firm birth. Differences can be found, but probably only for a small number of large companies, whose registered offices are often located in the most important Belgian cities, such as Brussels. Moreover, the geographical areas for which our data are collected are districts. In Belgium, districts

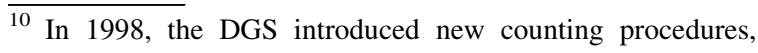
resolving this problem. Source: interview with the DGS.

11 There were 686,857 active taxable agents in Belgium in 2002, of which 499,376 were individuals (source: Economie, Démographie des enterprises, Direction Générale Statistique et Information Economique, Bruxelles, 2004), our computations).

12 Source: interview with the DGS.
} 
generally include a mix of countryside and small- and medium-sized towns vivifying their surroundings and, in all cases, relatively important entrepreneurial activities at the aggregated industry level can be observed in terms of firm births and deaths.

Although correct computation of the net entry rate implies dividing the net number of new entries by the stock of firms at $t-1$, the change to the new classification by the Belgian federal DGS leads us to approximate the proper value by using the stock of firms at time $t$. Data for annual gross regional value added, or gross regional product, at market prices is published by the Belgian National Accounts Institute. The national overall GDP deflator is used to measure economic growth in real terms in the 43 districts.

The summary statistics of firms' net entry, stocks, and net entry rates, and regional economic growth are presented in Tables 1 and 2. A distinction is made between manufacturing and services industries.

In view of firms' stocks and net entries figures (Table 1), entrepreneurial activity appears very unequal across districts. This emerges as a high standard deviation and is particularly relevant for services. In comparison with activity in the manufacturing industry, services are more present and dynamic, with an annual average per district of 9,547 for stocks and of 160 for net entries $(2,597$ and 43, respectively, for manufacturing). In fact, some exceptionally high values associated with the city districts of Brussels and Antwerp push up the averages. In terms of relative industrial dynamics and dispersion, the contrast is less noticeable when considering net entry rates, although variance across districts is still remarkable and appealing for research.

Growth figures (Table 2) depict dissimilar industrial and regional trajectories. Considering the average across districts of the average annual growth rates highlights the relatively low performance in manufacturing $(0.60 \%)$ compared with services industries (3.24\%). This reveals the relative shift from manufacturing to services taking place in Belgium during

Table 2 Average annual growth rates (AAGR), 1982-1996, in real terms

\begin{tabular}{|c|c|c|c|c|}
\hline & AAGR $(\%)$ & St. deviation & Min. & Max. \\
\hline \multicolumn{5}{|c|}{ Manufacturing industries } \\
\hline $\begin{array}{l}\text { Average across } \\
\text { districts }\end{array}$ & 0.60 & 1.84 & -3.82 & 5.09 \\
\hline Belgium & 0.85 & - & - & - \\
\hline \multicolumn{5}{|l|}{ Services industries } \\
\hline $\begin{array}{l}\text { Average across } \\
\text { districts }\end{array}$ & 3.24 & 0.78 & 1.65 & 4.67 \\
\hline Belgium & 2.79 & - & - & - \\
\hline
\end{tabular}

Table 1 Firms' net entry, stocks, and net entry rates, 1982-1996

\begin{tabular}{|c|c|c|c|c|}
\hline & Annual average & St. deviation & Min. & Max. \\
\hline \multicolumn{5}{|l|}{ Manufacturing industries } \\
\hline \multicolumn{5}{|c|}{ Average across districts } \\
\hline Net entry & 42.52 & 35.95 & -3.00 & 137.00 \\
\hline Stocks & $2,597.09$ & $2,341.00$ & 471.73 & $11,761.00$ \\
\hline Net entry rates $(\%)$ & 1.62 & 0.82 & -0.67 & 3.76 \\
\hline \multicolumn{5}{|l|}{ Belgium } \\
\hline Net entry & $1,828.40$ & - & - & - \\
\hline Stocks & $111,675.07$ & - & - & - \\
\hline Net entry rates $(\%)$ & 1.58 & - & - & - \\
\hline \multicolumn{5}{|l|}{ Services industries } \\
\hline \multicolumn{5}{|c|}{ Average across districts } \\
\hline Net entry & 160.06 & 246.23 & -6.87 & $1,334.93$ \\
\hline Stocks & $9,546.90$ & $10,903.21$ & $1,415.00$ & $59,144.20$ \\
\hline Net entry rates $(\%)$ & 1.30 & 0.76 & -0.45 & 2.81 \\
\hline \multicolumn{5}{|l|}{ Belgium } \\
\hline Net entry & $6,882.40$ & - & - & - \\
\hline Stocks & $410,516.80$ & - & - & - \\
\hline Net entry rates $(\%)$ & 1.66 & - & - & - \\
\hline
\end{tabular}


this period. Statistics show how much districts may be on very different tracks with high standard deviation around the average growth rate, in particular for manufacturing, and a large range between minimum and maximum values.

From the above-described dataset, we construct a sectorally adjusted net entry rate based on Fritsch (1996):

$\mathrm{NEN}_{i}^{t}=\frac{\sum_{j=1}^{n}\left(\mathrm{AEN}_{i j}^{t}-\mathrm{HEN}_{i j}^{t}\right)-\left(\mathrm{AEX}_{i j}^{t}-\mathrm{HEX}_{i j}^{t}\right)}{\mathrm{ST}_{i .}^{t}}$

with NEN, the sectorally adjusted net entry rate; AEN, the actual number of entries; HEN, the hypothetical number of entries; AEX, the actual number of exits; HEX, the hypothetical number of exits; ST, the stock of firms; $i$, region $i ; j$, industry $j ; t$, period $t$.

The hypothetical numbers of entries and exits correspond, respectively, to (2) and (3):

$$
\begin{aligned}
& \mathrm{HEN}_{i j}^{t}=\mathrm{ST}_{i j}^{t} \times \frac{\mathrm{AEN}_{. j}^{t}}{\mathrm{ST}_{. j}^{t}}, \\
& \mathrm{HEX}_{i j}^{t}=\mathrm{ST}_{i j}^{t} \times \frac{\mathrm{AEX}_{. j}^{t}}{\mathrm{ST}_{. j}^{t}} .
\end{aligned}
$$

This net entry rate, by emphasizing the local performance over the national average, serves as an indicator of the local entrepreneurial positioning with respect to expanding industries. ${ }^{13}$

The evolution of the regional value added, expressed in real terms, is given through the annual specific value added growth rate (SVAGR):

$\operatorname{SVAGR}_{i}^{t}=\left(\frac{\mathrm{VA}_{i}^{t}-\mathrm{VA}_{i}^{t-1}}{\mathrm{VA}_{i}^{t-1}}\right)-\mathrm{SVAGR}^{t}$.

Entrepreneurial and economic growth indicators are computed for all 43 Belgian districts. We consider 26 (30) subsectors for the manufacturing industry, and 22 (26) subsectors for the services industry, for the period 1982-1993 (1994-1996). The increase in the number of subsectors for the second period, 19941996, is a consequence of the new Classification of Economic Activities in the European Community (NACE, two-digit level) adopted in 1993 and implemented as of 1994.

\footnotetext{
${ }^{13}$ Note that a sectorally unadjusted net birth rate (UNEN) is also calculated (see Appendix).
}

\section{Empirical results}

The results of the empirical research are comprehensively presented, from the report of simple correlation analyses between the sectorally adjusted net entry rates of firms and the subsequent annual economic growth rates to more sophisticated regression and dynamic panel regression analyses.

\subsection{Correlations}

From the results in Tables 3 and 4, we can make some basic comments about the association between the sectorally adjusted net entry rates and subsequent economic growth in manufacturing and services. The results correspond to Pearson correlation coefficients between the two variables.

With respect to manufacturing, reviewing the correlation coefficients reveals very low and ambivalent coincidence, if any, with 41 positive and 43 negative coefficients (out of 105 reported coefficients), of which only 5 are significantly positive and 7 significantly negative (significance at, at least, the $10 \%$ level). For services, results in Table 4 lead to three comments. First, correlations are, in general, positive (84 out of 105 reported coefficients). Second, the intensity of the correlation is rather weak, with some noticeable exceptions. Twenty-six coefficients are positive and significant at $10 \%$ (of which 17 at $5 \%$ and 9 at $1 \%$ ). The value of the negative coefficients is generally low and insignificant, except for one. Third, there is a relative concentration of high positive coefficients in the $t+5$ growth rates column. ${ }^{14}$

If a relationship exists between the variables, basic correlation analyses reveal it to be tenuous and ambivalent in manufacturing. For services, it may be weak as well, although slightly more encouraging for the next regression analyses given the appearance of some noticeable significantly positive coefficients.

\subsection{Regression analyses}

The a priori posited impact of net entry on subsequent economic growth is tested using different

\footnotetext{
${ }^{14}$ Pearson correlation coefficients for the sectorally unadjusted indicators are reported in the Appendix.
} 
Table 3 Pearson correlation coefficients between adjusted net birth rates of firms and subsequent annual value added specific growth rates in the manufacturing industry

\begin{tabular}{|c|c|c|c|c|c|c|c|}
\hline \multirow[t]{2}{*}{ Net entry rates } & \multicolumn{7}{|c|}{ Annual value added specific growth rates (SVAGR) } \\
\hline & $t+0$ & $t+1$ & $t+2$ & $t+3$ & $t+4$ & $t+5$ & $t+6$ \\
\hline NEN96 & $\begin{array}{c}0.2231 \\
(0.1505)\end{array}$ & & & & & & \\
\hline NEN95 & $\begin{array}{r}-0.0163 \\
(0.9175)\end{array}$ & $\begin{array}{r}-0.0336 \\
(0.8306)\end{array}$ & & & & & \\
\hline NEN94 & $\begin{array}{c}0.5038 \\
(0.0006)\end{array}$ & $\begin{array}{c}0.0437 \\
(0.7807)\end{array}$ & $\begin{array}{c}0.1428 \\
(0.3609)\end{array}$ & & & & \\
\hline NEN93 & $\begin{array}{c}0.0261 \\
(0.8679)\end{array}$ & $\begin{array}{c}0.2281 \\
(0.1413)\end{array}$ & $\begin{array}{r}-0.0293 \\
(0.8520)\end{array}$ & $\begin{array}{r}-0.0895 \\
(0.5680)\end{array}$ & & & \\
\hline NEN92 & $\begin{array}{c}0.2295 \\
(0.1388)\end{array}$ & $\begin{array}{r}-0.0555 \\
(0.7236)\end{array}$ & $\begin{array}{c}0.1564 \\
(0.3165)\end{array}$ & $\begin{array}{r}-0.0135 \\
(0.9314)\end{array}$ & $\begin{array}{r}-0.2126 \\
(0.1712)\end{array}$ & & \\
\hline NEN91 & $\begin{array}{r}-0.3549 \\
(0.0195)\end{array}$ & $\begin{array}{c}0.2430 \\
(0.1164)\end{array}$ & $\begin{array}{c}0.2039 \\
(0.1897)\end{array}$ & $\begin{array}{c}0.1224 \\
(0.4343)\end{array}$ & $\begin{array}{c}0.0770 \\
(0.6237)\end{array}$ & $\begin{array}{c}0.0507 \\
(0.7466)\end{array}$ & \\
\hline NEN90 & $\begin{array}{c}0.0283 \\
(0.8569)\end{array}$ & $\begin{array}{c}0.1299 \\
(0.4064)\end{array}$ & $\begin{array}{r}-0.2057 \\
(0.1858)\end{array}$ & $\begin{array}{c}0.0847 \\
(0.5894)\end{array}$ & $\begin{array}{c}0.1673 \\
(0.2837)\end{array}$ & $\begin{array}{r}-0.0873 \\
(0.5776)\end{array}$ & $\begin{array}{c}0.1617 \\
(0.3001)\end{array}$ \\
\hline NEN89 & $\begin{array}{r}-0.0161 \\
(0.9183)\end{array}$ & $\begin{array}{r}-0.0813 \\
(0.6042)\end{array}$ & $\begin{array}{c}0.0082 \\
(0.9586)\end{array}$ & $\begin{array}{r}-0.1302 \\
(0.4052)\end{array}$ & $\begin{array}{c}0.2253 \\
(0.1463)\end{array}$ & $\begin{array}{c}0.1494 \\
(0.3391)\end{array}$ & $\begin{array}{r}-0.0890 \\
(0.5703)\end{array}$ \\
\hline NEN88 & $\begin{array}{c}0.3084 \\
(0.0442)\end{array}$ & $\begin{array}{c}0.0602 \\
(0.7016)\end{array}$ & $\begin{array}{r}-0.0296 \\
(0.8507)\end{array}$ & $\begin{array}{r}-0.3099 \\
(0.0431)\end{array}$ & $\begin{array}{c}0.3098 \\
(0.0432)\end{array}$ & $\begin{array}{r}-0.2005 \\
(0.1973)\end{array}$ & $\begin{array}{c}0.0035 \\
(0.9822)\end{array}$ \\
\hline NEN87 & $\begin{array}{r}-0.2461 \\
(0.1117)\end{array}$ & $\begin{array}{c}0.1211 \\
(0.4392)\end{array}$ & $\begin{array}{r}-0.0306 \\
(0.8453)\end{array}$ & $\begin{array}{r}-0.1166 \\
(0.4565)\end{array}$ & $\begin{array}{r}-0.0841 \\
(0.5917)\end{array}$ & $\begin{array}{c}0.1998 \\
(0.1990)\end{array}$ & $\begin{array}{r}-0.0213 \\
(0.8920)\end{array}$ \\
\hline NEN86 & $\begin{array}{r}-0.2746 \\
(0.0747)\end{array}$ & $\begin{array}{r}-0.0163 \\
(0.9176)\end{array}$ & $\begin{array}{r}-0.0788 \\
(0.6153)\end{array}$ & $\begin{array}{c}0.0562 \\
(0.7205)\end{array}$ & $\begin{array}{c}0.1591 \\
(0.3081)\end{array}$ & $\begin{array}{r}-0.0210 \\
(0.8939)\end{array}$ & $\begin{array}{c}0.0113 \\
(0.9429)\end{array}$ \\
\hline NEN85 & $\begin{array}{r}-0.2359 \\
(0.1278)\end{array}$ & $\begin{array}{c}0.0534 \\
(0.7339)\end{array}$ & $\begin{array}{r}-0.3227 \\
(0.0348)\end{array}$ & $\begin{array}{c}0.4240 \\
(0.0046)\end{array}$ & $\begin{array}{r}-0.0923 \\
(0.5561)\end{array}$ & $\begin{array}{r}-0.1453 \\
(0.3526)\end{array}$ & $\begin{array}{r}-0.1477 \\
(0.3446)\end{array}$ \\
\hline NEN84 & $\begin{array}{r}-0.0489 \\
(0.7553)\end{array}$ & $\begin{array}{r}-0.0045 \\
(0.9772)\end{array}$ & $\begin{array}{r}-0.2941 \\
(0.0556)\end{array}$ & $\begin{array}{r}-0.1944 \\
(0.2116)\end{array}$ & $\begin{array}{c}0.3187 \\
(0.0373)\end{array}$ & $\begin{array}{r}-0.0918 \\
(0.5582)\end{array}$ & $\begin{array}{r}-0.2262 \\
(0.1446)\end{array}$ \\
\hline NEN83 & $\begin{array}{r}-0.0623 \\
(0.6915)\end{array}$ & $\begin{array}{r}-0.4366 \\
(0.0034)\end{array}$ & $\begin{array}{c}0.1223 \\
(0.4346)\end{array}$ & $\begin{array}{c}0.0391 \\
(0.8034)\end{array}$ & $\begin{array}{r}-0.4711 \\
(0.0014)\end{array}$ & $\begin{array}{r}-0.0162 \\
(0.9178)\end{array}$ & $\begin{array}{r}-0.0454 \\
(0.7723)\end{array}$ \\
\hline NEN82 & $\begin{array}{c}0.1172 \\
(0.4543)\end{array}$ & $\begin{array}{c}0.2148 \\
(0.1666)\end{array}$ & $\begin{array}{c}0.0891 \\
(0.5698)\end{array}$ & $\begin{array}{c}0.1746 \\
(0.2627)\end{array}$ & $\begin{array}{c}0.2048 \\
(0.1876)\end{array}$ & $\begin{array}{c}0.1638 \\
(0.2940)\end{array}$ & $\begin{array}{r}-0.0705 \\
(0.6534)\end{array}$ \\
\hline
\end{tabular}

Significance in parenthesis

regression analyses, from Zellner's (1962) seemingly unrelated regression method applied to cross-section to least-squares dummy variable and panel dynamic models (Arellano and Bond 1991).

A first, crude approach to the evidence consists of estimating separate cross-sectional models for each year. This serves as a benchmark. An advantage is that the obtained results, by distinguishing on a yearly basis the estimated parameter values, reveal in a straightforward manner their relative constancy (or inconstancy) over time. $y_{i}=\alpha+\mathbf{x}_{i} \beta+\varepsilon_{i}$.

The dependent variable is the growth indicator, while the independent variables correspond to lagged net entry rates (from $t-1$ to $t-6$ ). ${ }^{15}$ Nine equations of this type were estimated by seemingly unrelated

$\overline{15}$ The occurrence of six lagged net entry variables in the estimated model raises the question of potential serial correlation of net entry or collinearity problems. Basic tests, available from the author, show that, if an issue, the obtained results are however quite satisfactory. Alternative modeling 
Table 4 Pearson correlation coefficients between adjusted net birth rates of firms and subsequent annual value added specific growth rates in the services industry

\begin{tabular}{|c|c|c|c|c|c|c|c|}
\hline \multirow[t]{2}{*}{ Net entry rates } & \multicolumn{7}{|c|}{ Annual value added specific growth rates (SVAGR) } \\
\hline & $t+0$ & $t+1$ & $t+2$ & $t+3$ & $t+4$ & $t+5$ & $t+6$ \\
\hline NEN96 & $\begin{array}{c}0.0779 \\
(0.6195)\end{array}$ & & & & & & \\
\hline NEN95 & $\begin{array}{c}0.3986 \\
(0.0081)\end{array}$ & $\begin{array}{c}0.0264 \\
(0.8666)\end{array}$ & & & & & \\
\hline NEN94 & $\begin{array}{c}0.0890 \\
(0.5705)\end{array}$ & $\begin{array}{c}0.4885 \\
(0.0009)\end{array}$ & $\begin{array}{c}0.2766 \\
(0.0725)\end{array}$ & & & & \\
\hline NEN93 & $\begin{array}{c}0.0896 \\
(0.5678)\end{array}$ & $\begin{array}{c}0.4252 \\
(0.0045)\end{array}$ & $\begin{array}{c}0.4022 \\
(0.0075)\end{array}$ & $\begin{array}{c}0.1884 \\
(0.2264)\end{array}$ & & & \\
\hline NEN92 & $\begin{array}{c}0.0493 \\
(0.7536)\end{array}$ & $\begin{array}{c}0.2458 \\
(0.1121)\end{array}$ & $\begin{array}{c}0.3038 \\
(0.0476)\end{array}$ & $\begin{array}{c}0.4207 \\
(0.0050)\end{array}$ & $\begin{array}{c}0.2594 \\
(0.0930)\end{array}$ & & \\
\hline NEN91 & $\begin{array}{c}0.3503 \\
(0.0213)\end{array}$ & $\begin{array}{c}0.1212 \\
(0.4389)\end{array}$ & $\begin{array}{r}-0.0909 \\
(0.5620)\end{array}$ & $\begin{array}{c}0.2259 \\
(0.1452)\end{array}$ & $\begin{array}{c}0.2050 \\
(0.1873)\end{array}$ & $\begin{array}{r}-0.0096 \\
(0.9511)\end{array}$ & \\
\hline NEN90 & $\begin{array}{c}0.3587 \\
(0.0182)\end{array}$ & $\begin{array}{r}-0.0589 \\
(0.7073)\end{array}$ & $\begin{array}{c}0.2542 \\
(0.1000)\end{array}$ & $\begin{array}{c}0.0452 \\
(0.7736)\end{array}$ & $\begin{array}{c}0.4336 \\
(0.0037)\end{array}$ & $\begin{array}{c}0.3845 \\
(0.0109)\end{array}$ & $\begin{array}{r}-0.1162 \\
(0.4581)\end{array}$ \\
\hline NEN89 & $\begin{array}{c}0.1289 \\
(0.4102)\end{array}$ & $\begin{array}{c}0.2940 \\
(0.0557)\end{array}$ & $\begin{array}{c}0.1174 \\
(0.4534)\end{array}$ & $\begin{array}{c}0.1079 \\
(0.4909)\end{array}$ & $\begin{array}{c}0.0927 \\
(0.5545)\end{array}$ & $\begin{array}{c}0.3556 \\
(0.0193)\end{array}$ & $\begin{array}{c}0.4168 \\
(0.0054)\end{array}$ \\
\hline NEN88 & $\begin{array}{c}0.0417 \\
(0.7908)\end{array}$ & $\begin{array}{c}0.0522 \\
(0.7395)\end{array}$ & $\begin{array}{c}0.0989 \\
(0.5280)\end{array}$ & $\begin{array}{c}0.0824 \\
(0.5995)\end{array}$ & $\begin{array}{r}-0.0969 \\
(0.5363)\end{array}$ & $\begin{array}{c}0.4388 \\
(0.0032)\end{array}$ & $\begin{array}{c}0.1219 \\
(0.4363)\end{array}$ \\
\hline NEN87 & $\begin{array}{r}-0.0330 \\
(0.8334)\end{array}$ & $\begin{array}{c}0.0171 \\
(0.9132)\end{array}$ & $\begin{array}{c}0.1911 \\
(0.2196)\end{array}$ & $\begin{array}{c}0.2901 \\
(0.0591)\end{array}$ & $\begin{array}{c}0.3349 \\
(0.0281)\end{array}$ & $\begin{array}{r}-0.1617 \\
(0.3003)\end{array}$ & $\begin{array}{c}0.1090 \\
(0.4864)\end{array}$ \\
\hline NEN86 & $\begin{array}{c}0.1621 \\
(0.2991)\end{array}$ & $\begin{array}{c}0.1880 \\
(0.2274)\end{array}$ & $\begin{array}{c}0.0890 \\
(0.5705)\end{array}$ & $\begin{array}{r}-0.1001 \\
(0.5232)\end{array}$ & $\begin{array}{c}0.0711 \\
(0.6505)\end{array}$ & $\begin{array}{r}-0.0289 \\
(0.8541)\end{array}$ & $\begin{array}{r}-0.3352 \\
(0.0280)\end{array}$ \\
\hline NEN85 & $\begin{array}{c}0.0239 \\
(0.8793)\end{array}$ & $\begin{array}{c}0.2545 \\
(0.0996)\end{array}$ & $\begin{array}{c}0.1368 \\
(0.3817)\end{array}$ & $\begin{array}{r}-0.0723 \\
(0.6449)\end{array}$ & $\begin{array}{c}0.1349 \\
(0.3883)\end{array}$ & $\begin{array}{c}0.3747 \\
(0.0133)\end{array}$ & $\begin{array}{c}0.0723 \\
(0.6449)\end{array}$ \\
\hline NEN84 & $\begin{array}{c}0.2191 \\
(0.1580)\end{array}$ & $\begin{array}{c}0.0798 \\
(0.6112)\end{array}$ & $\begin{array}{r}-0.0235 \\
(0.8809)\end{array}$ & $\begin{array}{c}0.2216 \\
(0.1532)\end{array}$ & $\begin{array}{c}0.0731 \\
(0.6411)\end{array}$ & $\begin{array}{c}0.3405 \\
(0.0254)\end{array}$ & $\begin{array}{c}0.0955 \\
(0.5422)\end{array}$ \\
\hline NEN83 & $\begin{array}{c}0.4616 \\
(0.0018)\end{array}$ & $\begin{array}{c}0.0673 \\
(0.6681)\end{array}$ & $\begin{array}{c}0.2675 \\
(0.0828)\end{array}$ & $\begin{array}{c}0.1290 \\
(0.4097)\end{array}$ & $\begin{array}{c}0.0971 \\
(0.5354)\end{array}$ & $\begin{array}{c}0.2833 \\
(0.0656)\end{array}$ & $\begin{array}{c}0.0718 \\
(0.6473)\end{array}$ \\
\hline NEN82 & $\begin{array}{r}-0.1314 \\
(0.4010)\end{array}$ & $\begin{array}{c}0.2853 \\
(0.0636)\end{array}$ & $\begin{array}{c}0.0591 \\
(0.7064)\end{array}$ & $\begin{array}{r}-0.0831 \\
(0.5963)\end{array}$ & $\begin{array}{c}0.0920 \\
(0.5575)\end{array}$ & $\begin{array}{c}0.0588 \\
(0.7079)\end{array}$ & $\begin{array}{c}0.2017 \\
(0.1947)\end{array}$ \\
\hline
\end{tabular}

Significance in parenthesis

regression (Zellner 1962). Zellner's method includes estimation for the full variance-covariance matrix of the coefficients, allowing the disturbances across equations to be correlated. The application of this method produces better results in terms of variance for the estimators. The regression outcomes are shown in Tables 5 and 6.

Footnote 15 continued

would have been to rely on average values of net entry rates, but we would have lost evidence of the wave patterns.
First, the general diagnostic statistics, chi-square, $P$-value, and $R$-square presented at the bottom of tables are examined. Although $R$-square statistics are flawed under generalized least-squares (GLS) estimation (Greene 2003), these are shown as rudimentary indicators of the model's explanatory power. In general, overall significance of the model appears very weak. This is particularly remarkable for manufacturing (Table 5), with only two regressions significant at a rather accommodating 5\% level. Statistics for services (Table 6) suggest as well a 
Table 5 Regression results for the manufacturing sector with sectorally adjusted net entry rates

\begin{tabular}{lccccccccc}
\hline & SVAGR88 & SVAGR89 & SVAGR90 & SVAGR91 & SVAGR92 & SVAGR93 & SVAGR94 & SVAGR95 & SVAGR96 \\
\hline Const. & 0.01 & -0.00 & -0.00 & $0.03 * *$ & 0.01 & -0.02 & -0.01 & 0.00 & 0.00 \\
NEN $t-1$ & -1.65 & 0.97 & -1.25 & 0.51 & 0.92 & -0.11 & $0.60^{* *}$ & 0.49 & 0.21 \\
NEN $t-2$ & -1.23 & -0.16 & -0.21 & 0.08 & $-1.21^{*}$ & $2.56^{* *}$ & 0.16 & -0.12 & 0.22 \\
NEN $t-3$ & $4.59 * *$ & 0.35 & 0.36 & $-1.38^{* *}$ & -0.62 & 0.42 & 0.26 & -0.44 & 0.14 \\
NEN $t-4$ & $2.57 *$ & -1.52 & $2.77^{* *}$ & 0.29 & $1.15^{* *}$ & $2.50^{* *}$ & $1.05^{* *}$ & 0.26 & $-1.03^{* *}$ \\
NEN $t-5$ & $-1.97^{* *}$ & 0.07 & 0.55 & 0.22 & 0.56 & $-1.82^{*}$ & 0.30 & -0.30 & 0.40 \\
NEN $t-6$ & $-2.16^{* *}$ & -0.18 & $-2.14 * *$ & -0.66 & -0.81 & 0.08 & -0.17 & -0.35 & $0.56^{*}$ \\
R-sq & 0.27 & 0.01 & 0.12 & 0.12 & 0.20 & 0.21 & 0.14 & 0.01 & 0.14 \\
Chi2 & 22.50 & 3.55 & 8.26 & 7.07 & 16.26 & 12.06 & 11.10 & 3.30 & 9.56 \\
$P$ & 0.0010 & 0.7378 & 0.2197 & 0.3145 & 0.0124 & 0.0607 & 0.0853 & 0.7707 & 0.1444 \\
\hline
\end{tabular}

* Significant at $10 \%, * *$ significant at $5 \%, * * *$ significant at $1 \%$

Table 6 Regression results for the services sector with sectorally adjusted net entry rates

\begin{tabular}{lccccccccc}
\hline & SVAGR88 & SVAGR89 & SVAGR90 & SVAGR91 & SVAGR92 & SVAGR93 & SVAGR94 & SVAGR95 & SVAGR96 \\
\hline Const. & 0.00 & 0.00 & $0.01 * * *$ & $0.01 * * *$ & $0.01 *$ & $0.01 * *$ & -0.00 & $0.00^{* *}$ & 0.00 \\
NEN $t-1$ & 0.02 & 0.03 & 0.37 & $-0.68 *$ & -0.31 & $1.22^{* * *}$ & $0.44^{* *}$ & $0.51^{* * *}$ & -0.12 \\
NEN $t-2$ & 0.20 & -0.18 & -0.31 & 0.73 & 0.38 & $-1.16^{* *}$ & -0.21 & -0.00 & $0.30^{*}$ \\
NEN $t-3$ & -0.27 & -0.22 & 0.17 & 0.13 & $0.94 *$ & -0.03 & -0.03 & 0.32 & 0.04 \\
NEN $t-4$ & -0.29 & 0.43 & 0.00 & $0.59 * *$ & -0.25 & -0.69 & $0.41^{* *}$ & -0.29 & $0.45^{* *}$ \\
NEN $t-5$ & $0.47 * *$ & $0.89 * *$ & $0.65 * *$ & -0.34 & $-0.60^{*}$ & $1.40^{* * *}$ & 0.29 & $0.41^{*}$ & -0.02 \\
NEN $t-6$ & $0.27 *$ & -0.10 & -0.05 & -0.30 & $-1.28 * * *$ & 0.28 & -0.21 & 0.27 & $-0.30^{*}$ \\
R-sq & 0.16 & 0.12 & 0.20 & 0.16 & 0.27 & 0.29 & 0.29 & 0.36 & 0.17 \\
Chi2 & 9.43 & 7.16 & 11.76 & 8.58 & 14.85 & 26.77 & 21.30 & 34.57 & 18.46 \\
$P$ & 0.1509 & 0.3065 & 0.0675 & 0.1987 & 0.0215 & 0.0002 & 0.0016 & 0.0000 & 0.0052 \\
\hline
\end{tabular}

* Significant at $10 \%, * *$ significant at $5 \%$, *** significant at $1 \%$

more circumstantiated set of comments, with a substantial improvement in overall significance of the model for the most recent years (1993, 1994, 1995, and 1996, although with an inflexion for 1996).

The increased goodness of fit emerging from the estimates over time for services may be compared with the results obtained by Audretsch and Fritsch (2002). ${ }^{16}$ These authors evaluate the contribution of new firms to regional employment growth and find evidence of an increased effect in the 1990s compared with the 1980s. They interpret the result as the shifting of German regions toward a more entrepreneurial regime in the 1990s. This shift itself may be related to a broader tendency in some economies to

$\overline{16}$ See also van Stel and Storey (2004). move from a managed to an entrepreneurial economy (Audretsch and Thurik 2000).

The impression derived from reviewing the parameter estimates of the regressions with overall significance (at 5\% level) is one of relative inconstancy over time. That being said, it is noticeable that coefficients show the usual wave pattern (Fritsch 2008).

For economic growth in manufacturing in 1988 and 1992, significantly positive effects of net entry in $t-3$ or in $t-4$ are, respectively, followed or preceded by significantly negative effects. Even if interpreted tentatively in terms of net effects by simply adding significant lagged effects, results do not allow distinction of whether the relation is in general positive or negative, as it appears positive in one case (1988) and negative in the other (1992).

For economic growth in services during the most recent period (1993-1996) significant positive effects 
emerge for the $t-1$ net entry rates in three out of four regressions, and for the $t-4$ or $t-5$ lagged net entry rates in all four regressions. Another significant, albeit isolated, positive effect emerges for the $t-2$ net entry rate in the 1996 regression. These results suggest that some districts grow at greater rates, since net entry was relatively higher there than in other districts during some prior years. However, it must be also emphasized that these positive relationships appear partly counterbalanced in 1993 and 1996 (and even more than counterbalanced in 1992) by significant negative effects.

Results for the 1992 and 1993 regressions are interesting given their contrasting distinctiveness. These years had weaker economic growth (corresponding even to an economic recession in 1993) than the preceding period, followed by a recovery in 1994. The relationship between the entrepreneurial demography and the business cycle constitutes a worthwhile topic for further exploration (cf. Koellinger and Thurik 2009; Congregado et al. 2009).

The inconsistency of estimates over time that is revealed through the above tables and comments leads to the conclusion that one should take into account time effects in the next least-squares dummy variable (LSDV) and panel dynamic models.

\subsection{Panel data analyses}

The dataset offers the opportunity to apply panel data models. As expected with data for economic entities such as states or regions, the Hausman (1978) specification test rejects the random-effects model. This test, together with the evidence of time inconstancy above, leads us to select a geographical and time fixed-effects model of the form:

$y_{i t}=\alpha+\mathbf{x}_{i t} \beta+v_{i}+\mu_{t}+\varepsilon_{i t}$.

Moreover, testing for heteroskedasticity on preliminary estimates suggests the use of the Huber-White sandwich robust standard errors.

The above seemingly unrelated regression results (Tables 5, 6), whatever their limitations, suggest an improvement in overall significance of the model for recent years regarding services. Hence, the model is tested on the complete dataset, as well as on a subset corresponding to the four last years (1993-1996). Estimates are reported in Tables 7 and 8.

Reviewing the results for manufacturing (Table 7), general diagnostic statistics, $F$-statistics and $P$-values, lead to the selection and discussion of only two of the six regression estimates, namely the two regressions for the more recent period 1993-1996 including district dummies. This suggests the relative difficulty in finding overall explanatory power of the proposed model. That being said, the significant negative effects of the emerging $t-5$ net entry rates are noteworthy enough to be emphasized. This effect is confirmed whenever district dummies or both district and time dummies are included. Although the result is questionable, it suggests that districts facing lower growth rates are also districts that were registering higher net entry rates with a 5-year delay. A tentative interpretation would be that new firms entering the manufacturing sector may have some negative impact on the district aggregate product growth, although the exact origin of the impact remains unknown. Is it related directly to the poor performance of the new firms after having acquired some maturity, or indirectly to some negative effects on the performance of the district economy, including incumbent firms, as a whole? Whatever it may be, a primary concern is how robust the result is and how to get confirmation of the lagged effect using another estimation method. It will be shown that it is not confirmed by dynamic panel estimates.

As shown by general diagnostic statistics included in Table 8, the specification of the model is accepted in all of the six reported regressions relating to the services industry. Results suggest that an important attribute for the explanatory power of the model is its inclusion of district dummies to control for local fixed effects. The model, when estimated for the entire 1988-1996 period, includes significant positive effect from past net entry, with a 5-year lag, in only one of the three reported regressions. There is no significant negative effect. Significant and positive 5year-lagged effects are also revealed from the subset of data relating to the more recent period, since the model includes district dummies. ${ }^{17}$ A positive relationship between growth and 1-year-lagged net entry is also noteworthy in the regression including only time dummies. Consistently with the estimates for the entire period, no significant negative effect shows up here. Given the small size of the dataset, the result is confirmed using bootstrapping procedures.

\footnotetext{
$\overline{17}$ For the sake of exhaustivity, note that the 5-year-lagged effect of net entry within the model with time dummies but no district dummies has a $P$-value of 0.141 .
} 
Table 7 Least-squares dummy variable (LSDV) model estimates: manufacturing industry

\begin{tabular}{|c|c|c|c|c|c|c|}
\hline & SVAGR 88-96 & SVAGR 88-96 & SVAGR 88-96 & SVAGR 93-96 & SVAGR 93-96 & SVAGR 93-96 \\
\hline NEN $t-1$ & $\begin{array}{l}0.236 \\
(0.339)\end{array}$ & $\begin{array}{l}0.341 \\
(0.301)\end{array}$ & $\begin{array}{l}0.241 \\
(0.340)\end{array}$ & $\begin{array}{l}-0.009 \\
(0.393)\end{array}$ & $\begin{array}{l}0.104 \\
(0.298)\end{array}$ & $\begin{array}{l}-0.102 \\
(0.384)\end{array}$ \\
\hline NEN $t-2$ & $\begin{array}{l}-0.210 \\
(0.336)\end{array}$ & $\begin{array}{l}-0.137 \\
(0.321)\end{array}$ & $\begin{array}{l}-0.222 \\
(0.338)\end{array}$ & $\begin{array}{l}-0.051 \\
(0.430)\end{array}$ & $\begin{array}{l}0.287 \\
(0.346)\end{array}$ & $\begin{array}{l}-0.130 \\
(0.429)\end{array}$ \\
\hline NEN $t-3$ & $\begin{array}{l}0.021 \\
(0.470)\end{array}$ & $\begin{array}{l}0.149 \\
(0.443)\end{array}$ & $\begin{array}{l}0.054 \\
(0.478)\end{array}$ & $\begin{array}{l}-0.337 \\
(0.304)\end{array}$ & $\begin{array}{l}-0.104 \\
(0.285)\end{array}$ & $\begin{array}{l}-0.443 \\
(0.306)\end{array}$ \\
\hline NEN $t-4$ & $\begin{array}{l}0.824 * \\
(0.468)\end{array}$ & $\begin{array}{l}0.929 * * \\
(0.435)\end{array}$ & $\begin{array}{l}0.856 * \\
(0.481)\end{array}$ & $\begin{array}{l}0.037 \\
(0.516)\end{array}$ & $\begin{array}{l}0.628 \\
(0.460)\end{array}$ & $\begin{array}{l}-0.123 \\
(0.520)\end{array}$ \\
\hline $\mathrm{NEN} t-5$ & $\begin{array}{l}-0.554 \\
(0.605)\end{array}$ & $\begin{array}{l}-0.456 \\
(0.617)\end{array}$ & $\begin{array}{l}-0.578 \\
(0.609)\end{array}$ & $\begin{array}{l}-1.024 * \\
(0.533)\end{array}$ & $\begin{array}{l}-0.482 \\
(0.573)\end{array}$ & $\begin{array}{l}-1.188 * * \\
(0.573)\end{array}$ \\
\hline NEN $t-6$ & $\begin{array}{l}-0.433 \\
(0.545)\end{array}$ & $\begin{array}{l}-0.444 \\
(0.427)\end{array}$ & $\begin{array}{l}-0.524 \\
(0.506)\end{array}$ & $\begin{array}{l}-0.457 \\
(0.506)\end{array}$ & $\begin{array}{l}-0.027 \\
(0.389)\end{array}$ & $\begin{array}{l}-0.563 \\
(0.510)\end{array}$ \\
\hline Constant & $\begin{array}{l}0.021 \\
(0.011)^{*}\end{array}$ & $\begin{array}{l}-0.003 \\
(0.007)\end{array}$ & $\begin{array}{l}0.016 \\
(0.015)\end{array}$ & $\begin{array}{l}0.010 \\
(0.011)\end{array}$ & $\begin{array}{l}-0.002 \\
(0.006)\end{array}$ & $\begin{array}{l}0.018 \\
(0.011)\end{array}$ \\
\hline District dummies & Yes & No & Yes & Yes & No & Yes \\
\hline Time dummies & No & Yes & Yes & No & Yes & Yes \\
\hline $\begin{array}{l}\text { Number of obs. } \\
F\end{array}$ & $\begin{array}{l}387 \\
(48,338)\end{array}$ & $\begin{array}{l}387 \\
(14,372)\end{array}$ & $\begin{array}{l}387 \\
(56,330)\end{array}$ & $\begin{array}{l}172 \\
(48,123)\end{array}$ & $\begin{array}{l}172 \\
(9,162)\end{array}$ & $\begin{array}{l}172 \\
(51,120)\end{array}$ \\
\hline & 1.11 & 1.18 & 1.13 & 1.46 & 0.86 & 1.62 \\
\hline$P$ & 0.3024 & 0.2857 & 0.2604 & 0.0499 & 0.5615 & 0.0172 \\
\hline$R$-squared & 0.0705 & 0.0498 & 0.0907 & 0.3084 & 0.0565 & 0.3402 \\
\hline
\end{tabular}

Huber/White/sandwich robust standard errors in parentheses

* Significant at $10 \%, * *$ significant at $5 \%$, *** significant at $1 \%$

Now, consider the autoregressive model:

$y_{i t}=\alpha+\gamma y_{i t-1}+\mathbf{x}_{i t} \beta+v_{i}+\mu_{t}+\varepsilon_{i t}$.

This model offers some interesting features. First, the occurrence of the autoregressive term $y_{i t-1}$ is to be identified as an attempt to correct for reversed causality and introduces a Granger-type approach to the problem, as suggested by van Stel and Suddle (2008) and Carree and Thurik (2008). Second, by taking the first difference $y_{i t}-y_{i t-1}$, the time-invariant $v_{i}$, geographical fixed effects, is dropped from the model. The remaining expression is estimated using the Arellano and Bond (1991) first-differenced generalized method of moments (GMM). We estimate the models without and with time dummies. The results are presented in Table 9.

Given Wald tests and $P$-values, specification of the model is accepted in all cases, except for the model relating to services without time dummies. For services, Arellano-Bond tests on average autocovariance in residuals reveal the very weak probability of the null hypothesis (no autocorrelation) with respect to residuals of order 1 , and a very high one as to residuals of order 2. As regards manufacturing, given results of the Arellano-Bond tests, the alternative models are investigated with two lags of the dependent variables included in the model. Insignificance of past net entry rates are just confirmed, as the deceleration effects suggested by the significant and negative sign of the coefficient from past growth (including $t-2$ ) on current growth. Moreover, rough tests, based on Moran's $I$, to detect potential spatial time-variant autocorrelation were conducted on the residual errors, without significant results. These test results lead to the conclusion that the estimated parameters are consistent.

Note that the pattern of growth in manufacturing is related to past growth and not to net entry rates. Referring to the effect of net entry rates, the results obtained here contradict the negative relationship revealed by the LSDV model estimates. As for services, results for the model with time dummies 
Table 8 Least-squares dummy variable (LSDV) model estimates: services industry

\begin{tabular}{|c|c|c|c|c|c|c|}
\hline & SVAGR 88-96 & SVAGR 88-96 & SVAGR 88-96 & SVAGR 93-96 & SVAGR 93-96 & SVAGR 93-96 \\
\hline \multirow[t]{2}{*}{ NEN $t-1$} & -0.014 & 0.179 & -0.029 & 0.160 & 0.380 & 0.162 \\
\hline & $(0.145)$ & $(0.126)$ & $(0.138)$ & $(0.218)$ & $(0.174)^{* *}$ & $(0.210)$ \\
\hline \multirow[t]{2}{*}{ NEN $t-2$} & -0.015 & 0.126 & 0.016 & -0.178 & -0.093 & -0.167 \\
\hline & $(0.136)$ & $(0.136)$ & $(0.143)$ & $(0.206)$ & $(0.182)$ & $(0.191)$ \\
\hline \multirow[t]{2}{*}{ NEN $t-3$} & -0.086 & -0.022 & -0.024 & 0.058 & -0.022 & 0.139 \\
\hline & $(0.146)$ & $(0.143)$ & $(0.147)$ & $(0.216)$ & $(0.257)$ & $(0.209)$ \\
\hline \multirow[t]{2}{*}{ NEN $t-4$} & 0.026 & 0.103 & 0.078 & 0.098 & 0.023 & 0.186 \\
\hline & $(0.132)$ & $(0.132)$ & $(0.137)$ & $(0.236)$ & $(0.214)$ & $(0.265)$ \\
\hline \multirow[t]{2}{*}{$\mathrm{NEN} t-5$} & 0.207 & $0.308 *$ & 0.240 & $0.606 *$ & 0.508 & $0.714^{*}$ \\
\hline & $(0.187)$ & $(0.172)$ & $(0.201)$ & $(0.339)$ & $(0.343)$ & $(0.410)$ \\
\hline \multirow[t]{2}{*}{ NEN $t-6$} & -0.165 & -0.036 & -0.149 & -0.028 & -0.052 & 0.007 \\
\hline & 0.116 & $(0.092)$ & $(0.117)$ & $(0.215)$ & $(0.143)$ & $(0.225)$ \\
\hline \multirow[t]{2}{*}{ Constant } & -0.003 & -0.001 & -0.006 & -0.007 & 0.000 & -0.002 \\
\hline & $(0.005)$ & $(0.002)$ & $(0.006)$ & $(0.005)$ & $(0.002)$ & $(0.007)$ \\
\hline District dummies & Yes & No & Yes & Yes & No & Yes \\
\hline Time dummies & No & Yes & Yes & No & Yes & Yes \\
\hline Number of obs. & 387 & 387 & 387 & 172 & 172 & 172 \\
\hline \multirow[t]{2}{*}{$F$} & $(48,338)$ & $(14,372)$ & $(56,330)$ & $(48,123)$ & $(9,162)$ & $(51,120)$ \\
\hline & 3.30 & 2.75 & 2.85 & 3.74 & 3.81 & 3.08 \\
\hline$P$ & 0.0000 & 0.0007 & 0.0000 & 0.0000 & 0.0002 & 0.0000 \\
\hline$R$-squared & 0.1775 & 0.0830 & 0.2061 & 0.3435 & 0.1548 & 0.3776 \\
\hline
\end{tabular}

Huber/White/sandwich robust standard errors in parentheses

* Significant at $10 \%$, ** significant at $5 \%$, *** significant at $1 \%$

indicate that the effect of 5-year-lagged net entry rates is significant (at the 0.10 level) and positive. ${ }^{18}$ Thus, although tenuous, the result confirms a positive lagged effect from net entry on economic growth.

\section{Conclusions}

Empirical evidence emphasizing the positive impact of entrepreneurship on economic performance at the

\footnotetext{
$\overline{18}$ For the purposes of comparison, for different contexts and models focusing on the lag structure, Fritsch and Mueller (2004) find that the highest positive impact of new firms on employment creation is about 8 years after entry, whereas Fritsch and Mueller (2008) estimate this lag to be around 7 years, and van Stel and Storey (2004) around 4.5 years. Given their dataset, Johnson and Parker (1996) were only able to assess 1- to 2-year-lagged effects on aggregate output derived from firm births and deaths. They found a strongly positive effect regarding $t-1$ births and a negative one regarding $t-1$ deaths. A $t-2$, weak but significant, negative effect from births was also unveiled.
}

firm level is found. The emerging picture is different at the regional and national levels and, more specifically, when economic performance is measured through the capacity of the aggregated economy to create new value. Even if the direct contribution of new firms to economic growth is regarded as tautological, the aggregate effects of new firms are largely empirically unnoticed. Therefore it seems that the entrepreneurial capacity of a region or country, materializing quantitatively through the flow of new firms, is most likely insufficient to explain, even partly, why differentiated economic growth rates are observed from one location to another. It is argued that an economic assessment of the relationship should pay more attention to the industry component of entrepreneurial processes.

In accordance with the industry lifecycle literature, positive net entry rates may be linked to new products and emerging industries. Additionally, there is empirical evidence, collected at the firm level, to posit a positive relationship between value added and 
Table 9 Arellano-Bond dynamic panel estimates in the manufacturing and services industries

\begin{tabular}{|c|c|c|c|c|}
\hline & \multicolumn{2}{|l|}{ Manufacturing } & \multicolumn{2}{|l|}{ Services } \\
\hline & SVAGR 88-96 & SVAGR 88-96 & SVAGR 88-96 & SVAGR 88-96 \\
\hline SVAGR $t-1$ & $\begin{array}{l}-0.291 * * * \\
(0.094)\end{array}$ & $\begin{array}{l}-0.298 * * * \\
(0.095)\end{array}$ & $\begin{array}{l}-0.067 \\
(0.076)\end{array}$ & $\begin{array}{l}-0.080 \\
(0.072)\end{array}$ \\
\hline NEN $t-1$ & $\begin{array}{l}0.375 \\
(0.355)\end{array}$ & $\begin{array}{l}0.342 \\
(0.360)\end{array}$ & $\begin{array}{l}-0.006 \\
(0.156)\end{array}$ & $\begin{array}{l}-0.043 \\
(0.164)\end{array}$ \\
\hline NEN $t-2$ & $\begin{array}{l}-0.002 \\
(0.313)\end{array}$ & $\begin{array}{l}-0.065 \\
(0.300)\end{array}$ & $\begin{array}{l}-0.020 \\
(0.096)\end{array}$ & $\begin{array}{l}0.019 \\
(0.109)\end{array}$ \\
\hline NEN $t-3$ & $\begin{array}{l}-0.089 \\
(0.358)\end{array}$ & $\begin{array}{l}-0.101 \\
(0.399)\end{array}$ & $\begin{array}{l}-0.100 \\
(0.166)\end{array}$ & $\begin{array}{l}-0.011 \\
(0.162)\end{array}$ \\
\hline $\mathrm{NEN} t-4$ & $\begin{array}{l}0.613 \\
(0.493)\end{array}$ & $\begin{array}{l}0.616 \\
(0.531)\end{array}$ & $\begin{array}{l}0.068 \\
(0.134)\end{array}$ & $\begin{array}{l}0.156 \\
(0.138)\end{array}$ \\
\hline $\mathrm{NEN} t-5$ & $\begin{array}{l}-0.600 \\
(0.692)\end{array}$ & $\begin{array}{l}-0.652 \\
(0.696)\end{array}$ & $\begin{array}{l}0.292 \\
(0.185)\end{array}$ & $\begin{array}{l}0.360 * \\
(0.205)\end{array}$ \\
\hline NEN $t-6$ & $\begin{array}{l}-0.626 \\
(0.515)\end{array}$ & $\begin{array}{l}-0.759 \\
(0.464)\end{array}$ & $\begin{array}{l}-0.087 \\
(0.114)\end{array}$ & $\begin{array}{l}-0.047 \\
(0.117)\end{array}$ \\
\hline Constant & $\begin{array}{l}-0.001 \\
(0.003)\end{array}$ & $\begin{array}{l}-0.002 \\
(0.003)\end{array}$ & $\begin{array}{l}0.000 \\
(0.000)\end{array}$ & $\begin{array}{l}-0.001 \\
(0.004)\end{array}$ \\
\hline Time dummies & No & Yes & No & Yes \\
\hline Number of obs. & 344 & 344 & 344 & 344 \\
\hline Wald Chi2 & (7) 56.90 & (14) 71.95 & (7) 4.26 & (14) 27.49 \\
\hline$P$ & 0.0000 & 0.0000 & 0.7495 & 0.0166 \\
\hline \multicolumn{5}{|c|}{ Arellano-Bond test on average autocovariance in residuals of order 1 is 0} \\
\hline H0: no autocorrelation $P$ & 0.0071 & 0.0070 & 0.0001 & 0.0001 \\
\hline \multicolumn{5}{|c|}{ Arellano-Bond test on average autocovariance in residuals of order 2 is 0} \\
\hline H0: no autocorrelation $P$ & 0.0468 & 0.0427 & 0.3183 & 0.3858 \\
\hline
\end{tabular}

Huber/White/sandwich robust standard errors in parentheses.

* Significant at $10 \%$, ** significant at $5 \%$, *** significant at $1 \%$

industries characterized by high turnover but a growing firm population, in other words positive net entry. That being said, there are numerous direct and indirect effects of new firms that determine the aggregate outcome in terms of industry value added. From the discussion comes the idea that the expected sign of the net effects is a priori unclear. It is noted as well that, for regions, extending into new industries facilitates self-reliance and attractiveness, contributing to lasting prosperity.

It is proposed that regions with entrepreneurial resources flowing into industries with the highest positive net entry rates are those achieving higher performance in terms of aggregate value added creation. Applying multiple econometric approaches to data from Belgian districts covering the period 1982-1996, it is found that the cause-effect relationship between regionally differentiated entrepreneurial activities and economic growth is far from being a unique, pervasive, and manifest relationship. That being said, this analysis supports the conclusion that the entrepreneurial dynamics at work within the manufacturing and services industries can be distinguished. ${ }^{19}$ The results for manufacturing suggest negative relationships between firm net entry and economic growth or, more probably, autoregressive relationships in the growth process. As for services, although tenuous results must be interpreted cautiously, statistical significance appears to support the conclusion that net entry may have positive lagged effects on regional economic growth. Our results for

$\overline{19}$ Bosma et al. (in this issue) reach comparable results for The Netherlands. 
GDP growth in the services industry, although rather weak, are by and large consistent with previous findings, for other countries, regarding entry and employment growth.

Acknowledgements The author is grateful to Michel Mignolet, Adam Lederer, Steven Klepper, Frédéric Gaspart, Michael Fritsch, Dirk Engel, Nicolas Debarsy, Martin Carree, David Audretsch, and two anonymous referees for their useful comments and suggestions on earlier versions of the manuscript.

Open Access This article is distributed under the terms of the Creative Commons Attribution Noncommercial License which permits any noncommercial use, distribution, and reproduction in any medium, provided the original author(s) and source are credited.

\section{Appendix: Correlation analysis with sectorally unadjusted indicators}

Tables 10 and 11 report the correlation analysis results for the sectorally unadjusted indicators.

$\mathrm{UNEN}_{i}^{t}=\frac{\left(\mathrm{AEN}_{\mathrm{i} .}^{\mathrm{t}}-\mathrm{HEN}_{\mathrm{i} .}^{\mathrm{t}}\right)-\left(\mathrm{AEX}_{\mathrm{i} .}^{\mathrm{t}}-\mathrm{HEX}_{\mathrm{i} .}^{\mathrm{t}}\right)}{\mathrm{ST}_{i .}^{t}}$.

Regarding manufacturing, very low and ambivalent coincidence, if any, is substantiated. As for services, results confirm general positive values for the coefficients with great disparities and a few weak negative correlations (except in one case) (Tables 10,11)

Table 10 Pearson correlation coefficients between firms' unadjusted net birth rates and subsequent annual growth rates in the manufacturing industry

\begin{tabular}{|c|c|c|c|c|c|c|c|}
\hline \multirow[t]{2}{*}{ Net entry rates } & \multicolumn{7}{|c|}{ Annual value added specific growth rates (SVAGR) } \\
\hline & $t+0$ & $t+1$ & $t+2$ & $t+3$ & $t+4$ & $t+5$ & $t+6$ \\
\hline UNEN96 & $\begin{array}{c}0.2082 \\
(0.1802)\end{array}$ & & & & & & \\
\hline UNEN95 & $\begin{array}{r}-0.0148 \\
(0.9247)\end{array}$ & $\begin{array}{r}-0.0401 \\
(0.7986)\end{array}$ & & & & & \\
\hline UNEN94 & $\begin{array}{c}0.4821 \\
(0.0011)\end{array}$ & $\begin{array}{c}0.0598 \\
(0.7035)\end{array}$ & $\begin{array}{c}0.1217 \\
(0.4368)\end{array}$ & & & & \\
\hline UNEN93 & $\begin{array}{c}0.0461 \\
(0.7689)\end{array}$ & $\begin{array}{c}0.2260 \\
(0.1450)\end{array}$ & $\begin{array}{r}-0.0223 \\
(0.8872)\end{array}$ & $\begin{array}{r}-0.0847 \\
(0.5890)\end{array}$ & & & \\
\hline UNEN92 & $\begin{array}{c}0.2286 \\
(0.1404)\end{array}$ & $\begin{array}{r}-0.0356 \\
(0.8205)\end{array}$ & $\begin{array}{c}0.1586 \\
(0.3098)\end{array}$ & $\begin{array}{r}-0.0028 \\
(0.9855)\end{array}$ & $\begin{array}{c}-0.2134 \\
(0.1695)\end{array}$ & & \\
\hline UNEN91 & $\begin{array}{r}-0.3366 \\
(0.0273)\end{array}$ & $\begin{array}{c}0.2349 \\
(0.1295)\end{array}$ & $\begin{array}{c}0.2490 \\
(0.1073)\end{array}$ & $\begin{array}{c}0.1264 \\
(0.4191)\end{array}$ & $\begin{array}{c}0.0913 \\
(0.5604)\end{array}$ & $\begin{array}{c}0.0523 \\
(0.7392)\end{array}$ & \\
\hline UNEN90 & $\begin{array}{c}0.0111 \\
(0.9435)\end{array}$ & $\begin{array}{c}0.1682 \\
(0.2810)\end{array}$ & $\begin{array}{r}-0.2239 \\
(0.1488)\end{array}$ & $\begin{array}{c}0.1124 \\
(0.4730)\end{array}$ & $\begin{array}{c}0.1688 \\
(0.2791)\end{array}$ & $\begin{array}{r}-0.0789 \\
(0.6149)\end{array}$ & $\begin{array}{c}0.1682 \\
(0.2809)\end{array}$ \\
\hline UNEN89 & $\begin{array}{r}-0.0466 \\
(0.7668)\end{array}$ & $\begin{array}{r}-0.1023 \\
(0.5141)\end{array}$ & $\begin{array}{c}0.0357 \\
(0.8203)\end{array}$ & $\begin{array}{r}-0.1516 \\
(0.3318)\end{array}$ & $\begin{array}{c}0.2564 \\
(0.0969)\end{array}$ & $\begin{array}{c}0.1398 \\
(0.3713)\end{array}$ & $\begin{array}{c}-0.0757 \\
(0.6293)\end{array}$ \\
\hline UNEN88 & $\begin{array}{c}0.3137 \\
(0.0405)\end{array}$ & $\begin{array}{c}0.0518 \\
(0.7413)\end{array}$ & $\begin{array}{c}-0.0467 \\
(0.7664)\end{array}$ & $\begin{array}{r}-0.2981 \\
(0.0522)\end{array}$ & $\begin{array}{c}0.3015 \\
(0.0494)\end{array}$ & $\begin{array}{r}-0.1873 \\
(0.2291)\end{array}$ & $\begin{array}{c}-0.0015 \\
(0.9922)\end{array}$ \\
\hline UNEN87 & $\begin{array}{c}-0.2255 \\
(0.1460)\end{array}$ & $\begin{array}{c}0.1317 \\
(0.3999)\end{array}$ & $\begin{array}{c}-0.0580 \\
(0.7120)\end{array}$ & $\begin{array}{r}-0.1327 \\
(0.3964)\end{array}$ & $\begin{array}{c}-0.0506 \\
(0.7472)\end{array}$ & $\begin{array}{c}0.1765 \\
(0.2575)\end{array}$ & $\begin{array}{c}0.0012 \\
(0.9941)\end{array}$ \\
\hline UNEN86 & $\begin{array}{r}-0.3379 \\
(0.0267)\end{array}$ & $\begin{array}{c}-0.0129 \\
(0.9344)\end{array}$ & $\begin{array}{c}-0.0676 \\
(0.6668)\end{array}$ & $\begin{array}{c}0.0508 \\
(0.7462)\end{array}$ & $\begin{array}{c}0.1390 \\
(0.3740)\end{array}$ & $\begin{array}{c}-0.0194 \\
(0.9017)\end{array}$ & $\begin{array}{c}-0.0065 \\
(0.9672)\end{array}$ \\
\hline UNEN85 & $\begin{array}{r}-0.2354 \\
(0.1287)\end{array}$ & $\begin{array}{r}-0.0002 \\
(0.9989)\end{array}$ & $\begin{array}{c}-0.3224 \\
(0.0350)\end{array}$ & $\begin{array}{c}0.4360 \\
(0.0035)\end{array}$ & $\begin{array}{c}-0.1179 \\
(0.4515)\end{array}$ & $\begin{array}{c}-0.1518 \\
(0.3311)\end{array}$ & $\begin{array}{c}-0.1277 \\
(0.4147)\end{array}$ \\
\hline UNEN84 & $\begin{array}{r}-0.0530 \\
(0.7356)\end{array}$ & $\begin{array}{c}0.0003 \\
(0.9987)\end{array}$ & $\begin{array}{r}-0.3366 \\
(0.0273)\end{array}$ & $\begin{array}{r}-0.1833 \\
(0.2394)\end{array}$ & $\begin{array}{c}0.3156 \\
(0.0392)\end{array}$ & $\begin{array}{r}-0.1086 \\
(0.4882)\end{array}$ & $\begin{array}{c}-0.2339 \\
(0.1311)\end{array}$ \\
\hline
\end{tabular}


Table 10 continued

\begin{tabular}{lccccccc}
\hline Net entry rates & \multicolumn{2}{l}{ Annual value added specific growth rates (SVAGR) } \\
\cline { 2 - 7 } & $t+0$ & $t+1$ & $t+2$ & $t+3$ & $t+4$ & $t+5$ & $t+6$ \\
\hline UNEN83 & -0.0703 & -0.4341 & 0.1204 & -0.0023 & -0.4751 & -0.0174 & -0.0586 \\
& $(0.6540)$ & $(0.0036)$ & $(0.4417)$ & $(0.9884)$ & $(0.0013)$ & $(0.9118)$ & $(0.7089)$ \\
UNEN82 & 0.1320 & 0.2032 & 0.0971 & 0.1702 & 0.1895 & 0.1677 & -0.0576 \\
& $(0.3988)$ & $(0.1912)$ & $(0.5357)$ & $(0.2753)$ & $(0.2236)$ & $(0.2824)$ & $(0.7138)$ \\
& & & &
\end{tabular}

Significance in parenthesis

Table 11 Pearson correlation coefficients between firms' unadjusted net birth rates and subsequent annual growth rates in the services industry

\begin{tabular}{|c|c|c|c|c|c|c|c|}
\hline \multirow[t]{2}{*}{ Net entry rates } & \multicolumn{7}{|c|}{ Annual value added specific growth rates (SVAGR) } \\
\hline & $t+0$ & $t+1$ & $t+2$ & $t+3$ & $t+4$ & $t+5$ & $t+6$ \\
\hline UNEN96 & $\begin{array}{c}0.0800 \\
(0.6102)\end{array}$ & & & & & & \\
\hline UNEN95 & $\begin{array}{c}0.3380 \\
(0.0266)\end{array}$ & $\begin{array}{c}0.0212 \\
(0.8927)\end{array}$ & & & & & \\
\hline UNEN94 & $\begin{array}{c}0.1510 \\
(0.3338)\end{array}$ & $\begin{array}{c}0.4492 \\
(0.0025)\end{array}$ & $\begin{array}{c}0.2812 \\
(0.0678)\end{array}$ & & & & \\
\hline UNEN93 & $\begin{array}{c}0.0246 \\
(0.8754)\end{array}$ & $\begin{array}{c}0.4899 \\
(0.0009)\end{array}$ & $\begin{array}{c}0.2833 \\
(0.0656)\end{array}$ & $\begin{array}{c}0.1541 \\
(0.3240)\end{array}$ & & & \\
\hline UNEN92 & $\begin{array}{r}-0.0419 \\
(0.7896)\end{array}$ & $\begin{array}{c}0.1748 \\
(0.2622)\end{array}$ & $\begin{array}{c}0.3750 \\
(0.0132)\end{array}$ & $\begin{array}{c}0.3222 \\
(0.0351)\end{array}$ & $\begin{array}{c}0.2254 \\
(0.1462)\end{array}$ & & \\
\hline UNEN91 & $\begin{array}{c}0.3297 \\
(0.0309)\end{array}$ & $\begin{array}{r}-0.0083 \\
(0.9580)\end{array}$ & $\begin{array}{r}-0.1562 \\
(0.3171)\end{array}$ & $\begin{array}{c}0.2985 \\
(0.0519)\end{array}$ & $\begin{array}{c}0.0685 \\
(0.6624)\end{array}$ & $\begin{array}{r}-0.0429 \\
(0.7849)\end{array}$ & \\
\hline UNEN90 & $\begin{array}{c}0.2707 \\
(0.0792)\end{array}$ & $\begin{array}{r}-0.0138 \\
(0.9301)\end{array}$ & $\begin{array}{c}0.1178 \\
(0.4520)\end{array}$ & $\begin{array}{r}-0.0391 \\
(0.8036)\end{array}$ & $\begin{array}{c}0.4691 \\
(0.0015)\end{array}$ & $\begin{array}{c}0.2103 \\
(0.1758)\end{array}$ & $\begin{array}{r}-0.1552 \\
(0.3204)\end{array}$ \\
\hline UNEN89 & $\begin{array}{c}0.1505 \\
(0.3354)\end{array}$ & $\begin{array}{c}0.1905 \\
(0.2210)\end{array}$ & $\begin{array}{c}0.1326 \\
(0.3965)\end{array}$ & $\begin{array}{r}-0.0051 \\
(0.9742)\end{array}$ & $\begin{array}{r}-0.0035 \\
(0.9824)\end{array}$ & $\begin{array}{c}0.3733 \\
(0.0137)\end{array}$ & $\begin{array}{c}0.2190 \\
(0.1582)\end{array}$ \\
\hline UNEN88 & $\begin{array}{r}-0.0418 \\
(0.7902)\end{array}$ & $\begin{array}{c}0.0771 \\
(0.6232)\end{array}$ & $\begin{array}{c}0.0313 \\
(0.8420)\end{array}$ & $\begin{array}{c}0.1007 \\
(0.5205)\end{array}$ & $\begin{array}{r}-0.1708 \\
(0.2735)\end{array}$ & $\begin{array}{c}0.2989 \\
(0.0515)\end{array}$ & $\begin{array}{c}0.1504 \\
(0.3356)\end{array}$ \\
\hline UNEN87 & $\begin{array}{r}-0.1380 \\
(0.3774)\end{array}$ & $\begin{array}{r}-0.0561 \\
(0.7208)\end{array}$ & $\begin{array}{c}0.1913 \\
(0.2191)\end{array}$ & $\begin{array}{c}0.2104 \\
(0.1757)\end{array}$ & $\begin{array}{c}0.3199 \\
(0.0365)\end{array}$ & $\begin{array}{r}-0.2117 \\
(0.1730)\end{array}$ & $\begin{array}{c}0.0412 \\
(0.7930)\end{array}$ \\
\hline UNEN86 & $\begin{array}{c}0.0553 \\
(0.7246)\end{array}$ & $\begin{array}{c}0.0596 \\
(0.7040)\end{array}$ & $\begin{array}{c}0.0062 \\
(0.9686)\end{array}$ & $\begin{array}{r}-0.0604 \\
(0.7005)\end{array}$ & $\begin{array}{c}0.0364 \\
(0.8168)\end{array}$ & $\begin{array}{c}0.0228 \\
(0.8846)\end{array}$ & $\begin{array}{r}-0.3762 \\
(0.0129)\end{array}$ \\
\hline UNEN85 & $\begin{array}{r}-0.0431 \\
(0.7836)\end{array}$ & $\begin{array}{c}0.1539 \\
(0.3245)\end{array}$ & $\begin{array}{c}0.0178 \\
(0.9099)\end{array}$ & $\begin{array}{r}-0.1333 \\
(0.3942)\end{array}$ & $\begin{array}{c}0.1741 \\
(0.2643)\end{array}$ & $\begin{array}{c}0.3237 \\
(0.0342)\end{array}$ & $\begin{array}{c}0.1290 \\
(0.4095)\end{array}$ \\
\hline UNEN84 & $\begin{array}{c}0.1925 \\
(0.2162)\end{array}$ & $\begin{array}{c}0.0376 \\
(0.8106)\end{array}$ & $\begin{array}{r}-0.1078 \\
(0.4916)\end{array}$ & $\begin{array}{c}0.1092 \\
(0.4858)\end{array}$ & $\begin{array}{c}0.0127 \\
(0.9358)\end{array}$ & $\begin{array}{c}0.3575 \\
(0.0186)\end{array}$ & $\begin{array}{c}0.0627 \\
(0.6894)\end{array}$ \\
\hline UNEN83 & $\begin{array}{c}0.3401 \\
(0.0256)\end{array}$ & $\begin{array}{r}-0.0162 \\
(0.9180)\end{array}$ & $\begin{array}{c}0.1204 \\
(0.4420)\end{array}$ & $\begin{array}{c}0.0598 \\
(0.7034)\end{array}$ & $\begin{array}{r}-0.0148 \\
(0.9250)\end{array}$ & $\begin{array}{c}0.2520 \\
(0.1031)\end{array}$ & $\begin{array}{c}0.0874 \\
(0.5773)\end{array}$ \\
\hline UNEN82 & $\begin{array}{r}-0.1572 \\
(0.3140)\end{array}$ & $\begin{array}{c}0.2947 \\
(0.0551)\end{array}$ & $\begin{array}{c}0.0979 \\
(0.5323)\end{array}$ & $\begin{array}{r}-0.0350 \\
(0.8236)\end{array}$ & $\begin{array}{c}0.0851 \\
(0.5875)\end{array}$ & $\begin{array}{c}0.0689 \\
(0.6605)\end{array}$ & $\begin{array}{c}0.2042 \\
(0.1890)\end{array}$ \\
\hline
\end{tabular}

Significance in parenthesis 


\section{References}

Acs, Z. J., \& Armington, C. (2002). The determinants of regional variation in new firm formation. Regional Studies, 36(1), 33-45.

Acs, Z. J., \& Armington, C. (2004). Employment growth and entrepreneurial activity in cities. Regional Studies, 38(8), 911-927.

Agarwal, R., \& Gort, M. (1996). The evolution of markets and entry, exit and survival of firms. Review of Economics and Statistics, 78(3), 489-498.

Aghion, P., \& Howitt, P. (1992). A model of growth through creative destruction. Econometrica, 60(2), 323-351.

Aghion, P., \& Howitt, P. (1998). Endogenous growth theory. Cambridge, Massachusetts: MIT Press.

Arellano, M., \& Bond, S. (1991). Some tests of specification for panel data: Monte Carlo evidence and an application to employment equations. Review of Economic Studies, 58(2), 277-297.

Ashcroft, B., \& Love, J. H. (1996). Firm births and employment change in the British counties: 1981-1989. Papers in Regional Science, 75(4), 483-500.

Ashcroft, B., Plotnikova, M., \& Ritchie, D. (2007). New firm formation in British counties: Comparing the 1990s with the 1980s. Working Paper no 6, February, Centre for Public Policy for Regions.

Audretsch, D. B. (1995). Innovation and industry evolution. Cambridge, Massachusetts: MIT Press.

Audretsch, D. B. (2002). Entrepreneurship: a survey of the literature. Prepared for the European Commission, Enterprise Directorate General, July, mimeo.

Audretsch, D. B., \& Fritsch, M. (1996). Creative destruction: turbulence and economic growth in Germany. In E. Helmstädter \& M. Perlman (Eds.), Behavioral norms, technological progress, and economic dynamics: studies in Schumpeterian economics (pp. 137-150). Ann Arbor: University of Michigan Press.

Audretsch, D. B., \& Fritsch, M. (2002). Growth regimes over time and space. Regional Studies, 36(2), 113-124.

Audrestch, D. B., Keilbach, M. C., \& Lehmann, E. E. (2006). Entrepreneurship and economic growth. Oxford: Oxford University Press.

Audretsch, D. B., \& Thurik, A. R. (2000). Capitalism and democracy in the 21st Century: from the managed to the entrepreneurial economy. Journal of Evolutionary Economics, 10(1-2), 17-34.

Azevedo Lobo, C., \& Da Silva Costa, J. (2003). New firm formation: an empirical study for Portugal. International conference, Regional Studies Association, Pisa.

Baumol, W. J., Panzar, J. C., \& Willig, R. D. (1982). Contestable markets and the theory of industrial structure. New York: Harcourt Brace Jovanovich.

Beesley, M. E., \& Hamilton, R. T. (1984). Small firms' seedbed role and the concept of turbulence. Journal of Industrial Economics, 33(2), 217-231.

Bosma, N., Stam, E., \& Schutjens, V. (in this issue). Creative destruction and regional productivity growth: Evidence from the Dutch manufacturing and services industries. Small Business Economics.
Braunerhjelm, P., \& Borgman, B. (2004). Geographical concentration, entrepreneurship and regional growth: evidence from regional data in Sweden, 1975-99. Regional Studies, 38(8), 929-947.

Callejon, M., \& Segarra, A. (1999). Business dynamics and efficiency in industries and regions: the case of Spain. Small Business Economics, 13(4), 253-271.

Carree, M. A., \& Thurik, A. R. (2003). The impact of entrepreneurship on economic growth. In Z. J. Acs \& D. B. Audretsch (Eds.), Handbook of entrepreneurship research (pp. 437-471). Dordrecht: Kluwer Academic.

Carree, M. A., \& Thurik, A. R. (2008). The lag structure of the impact of business ownership on economic performance in OECD Countries. Small Business Economics, 30(1), $101-110$.

Caves, R. E. (1998). Industrial organization and new findings on the turnover and mobility of firms. Journal of Economic Literature, 36(4), 1947-1982.

Congregado, E., Golpe, A., \& Parker, S. (2009). The dynamics of entrepreneurship: hysteresis, business cycles and government policy. IZA Discussion Papers 4093, Institute for the Study of Labor (IZA).

Foelster, S. (2000). Do entrepreneurs create jobs? Small Business Economics, 14(2), 137-148.

Foster, L., Haltiwanger, J., \& Krizan, C. J. (1998). Aggregate productivity growth: Lessons from microeconomic evidence. Working Paper No 6803, Cambridge, MA, National Bureau of Economic Research.

Friis, C., Karlsson, C., \& Paulsson, T. (2006). Relating entrepreneurship to economic growth. In B. Johansson, C. Karlsson, \& R. Stough (Eds.), The emerging digital economy. Entrepreneurship, clusters, policy (pp. 83-111). Heidelberg: Springer.

Fritsch, M. (1996). Turbulence and growth in West Germany: a comparison of evidence by regions and industries. Review of Industrial Organisation, 11(2), 231-251.

Fritsch, M. (1997). New firms and regional employment change. Small Business Economics, 9(5), 437-448.

Fritsch, M. (ed). (2008). The effects of new businesses on economic development. Special issue. Small Business Economics, 30(1).

Fritsch, M., \& Mueller, P. (2004). Effects of new business formation on regional development over time. Regional Studies, 38(8), 961-975.

Fritsch, M., \& Mueller, P. (2008). The effect of new business formation on regional development over time: the case of Germany. Small Business Economics, 30(1), 15-29.

Gaygisiz, E., \& Köksal, M. Y. (2003). Regional variation in new firm formation in Turkey: cross-section and panel data evidence. ERC Working Papers in Economics 03/08.

Geroski, P. A. (1995). What do we know about entry? International Journal of Industrial Organization, 13(4), 421-440.

Gort, M., \& Klepper, S. (1982). Time paths in the diffusion of product innovations. Economic Journal, 92(367), 630-653.

Greene, W. H. (2003). Econometric analysis (5th ed.). Upper Saddle River, NJ: Prentice-Hall.

Hausman, J. (1978). Specification tests in econometrics. Econometrica, 46(6), 1251-1271. 
Johnson, P., \& Parker, S. (1996). Spatial variations in the determinants and effects of firm births and deaths. Regional Studies, 30(7), 679-688.

Jovanovic, B., \& MacDonald, G. M. (1994). The life cycle of a competitive industry. Journal of Political Economy, 102(2), 322-347.

Kangasharju, A. (2000). Regional variations in firm formation: panel and cross-section data evidence from Finland. Papers in Regional Science, 79(4), 355-373.

Klepper, S. (1996). Entry, exit, growth, and innovation over the product life cycle. American Economic Review, 86(3), 562-583.

Klepper, S., \& Graddy, E. (1990). The evolution of new industries and the determinants of market structure. RAND Journal of Economics, 21(1), 27-44.

Koellinger, P. D., \& Thurik, A. R. (2009). Entrepreneurship and the business cycle. Tinbergen Institute Discussion Papers 09-032/3, Tinbergen Institute, revised 30 June 2009.

Peneder, M. (2008). Firm entry and turnover: the nexus with profitability and growth. Small Business Economics, 30(4), 327-344.

Reilly, W. L. (1931). The law of retail gravitation. New York: Knickerbocker.

Reynolds, P., \& La Plant, D. (1993). Résumé national: Japon. In P. Reynolds \& D. J. Storey (Eds.), Déterminants régionaux de la création de petites entreprises - une comparaison entre plusieurs pays. Cahiers ILE $\mathrm{n}^{\circ} 18$, Paris: OCDE.

Reynolds, P., Storey, D. J., \& Westhead, P. (1994). Crossnational comparisons of the variation in new firm formation rates. Regional Studies, 28(4), 343-346.
Schumpeter, J. A. (1911), Theorie der wirtschaftlichen Entwicklung. Eine Untersuchung über Unternehmergewinn, Kapital, Kredit, Zins und den Konjunkturzyklus. Translated by R. Opie (1963 [1934]), The theory of economic development. An inquiry into profits, capital, credit, interest, and the business cycle, Oxford: Oxford University Press.

Schumpeter, J. A. (1942). Capitalism, socialism and democracy. New York: Harper and Row.

Spilling, O. R. (1996). Regional variation of new firm formation: the Norwegian case. Entrepreneurship and regional development, 8(3), 217-244.

Storey, D. J. (1994). Understanding the small business sector. London: Routledge.

van Stel, A. J., Carree, M. A., \& Thurik, A. R. (2005). The effect of entrepreneurial activity on national economic growth. Small Business Economics, 24(3), 301-321.

van Stel, A. J., \& Storey, D. J. (2004). The link between firm births and job creation: is there a Upas Tree effect? Regional Studies, 38(8), 893-909.

van Stel, A. J., \& Suddle, K. (2008). The impact of new firm formation on regional development in the Netherlands. Small Business Economics, 30(1), 31-47.

Wennekers, S., \& Thurik, A. R. (1999). Linking entrepreneurship and economic growth. Small Business Economics, 13(1), 27-55.

Zellner, A. (1962). An efficient method of estimating seemingly unrelated regressions and tests for aggregation bias. Journal of the American Statistical Association, 57(298), 348-368. 